\title{
Lithium-induced cortical atrophy and cognitive dysfunction
}

\author{
Alper Evrensel, Barış Önen Ünsalver, Mehmet Emin Ceylan, Gökçe Cömert
}

Department of Psychiatry, Uskudar University, İstanbul, Turkey

\section{Correspondence to} Dr Alper Evrensel, alperevrensel@gmail.com

Accepted 28 November 2014

CrossMark

To cite: Evrensel $A$, Ünsalver BarışÖ, Ceylan ME, et al. BMJ Case Rep Published online: [please include Day Month Year] doi:10.1136/bcr-2014207646

\section{DESCRIPTION}

A 50-year-old woman presented to the psychiatry clinic with symptoms of forgetfulness, distractibility and difficulty in absorbing information. She was started on lithium after a manic episode 10 years earlier and had been on lithium $900 \mathrm{mg} /$ day for the past 10 years. During this period her mood had remained stable and she was euthymic. However, her occupational and social functioning was impaired significantly in the past year. She had no family history of bipolar disorder or dementia. No medical condition was detected as an explanation of her forgetfulness. Cranial MRI and quantitative electroencephalography (QEEG) were performed. Bilateral temporoparietal cortical atrophy and lateral ventricular asymmetry were detected in her MRI (figure 1). Increase in $\theta$ and $\delta$ frequency was detected in her QEEG without any paroxysmal activity (figure 2). Lithium was stopped, and 6 weeks after lithium withdrawal neuropsychological tests demonstrated significant improvement in the patient's cognitive functions. Mini Mental
State Examination scores increased from 25 to 30. The $\theta$ and $\delta$ waves disappeared and QEEG was normalised (figure 3 ).

Neuroprotective effects of lithium have been reported. ${ }^{1}$ In these reports, the duration of lifetime exposure to lithium was not known. In the prospective studies lithium was used short term (several weeks). ${ }^{1}$ Unlike these studies, impairment in cognitive function due to long-term use of lithium has been found. ${ }^{2}{ }^{3}$ It is not known how chronic use of lithium makes changes in the brain and the hippocampus volume. Lithium has toxic effects on the thyroid gland and the kidney. Although it achieves a neuroprotective effect in a short time, it might also have a neurotoxic effect in the long run. In this case, cortical atrophy and cognitive dysfunction are thought to be due to long-term lithium use. In patients who use longterm lithium not only should their thyroid and the kidney functions be monitored but their cognitive functions and changes in their brain volume should also be checked.

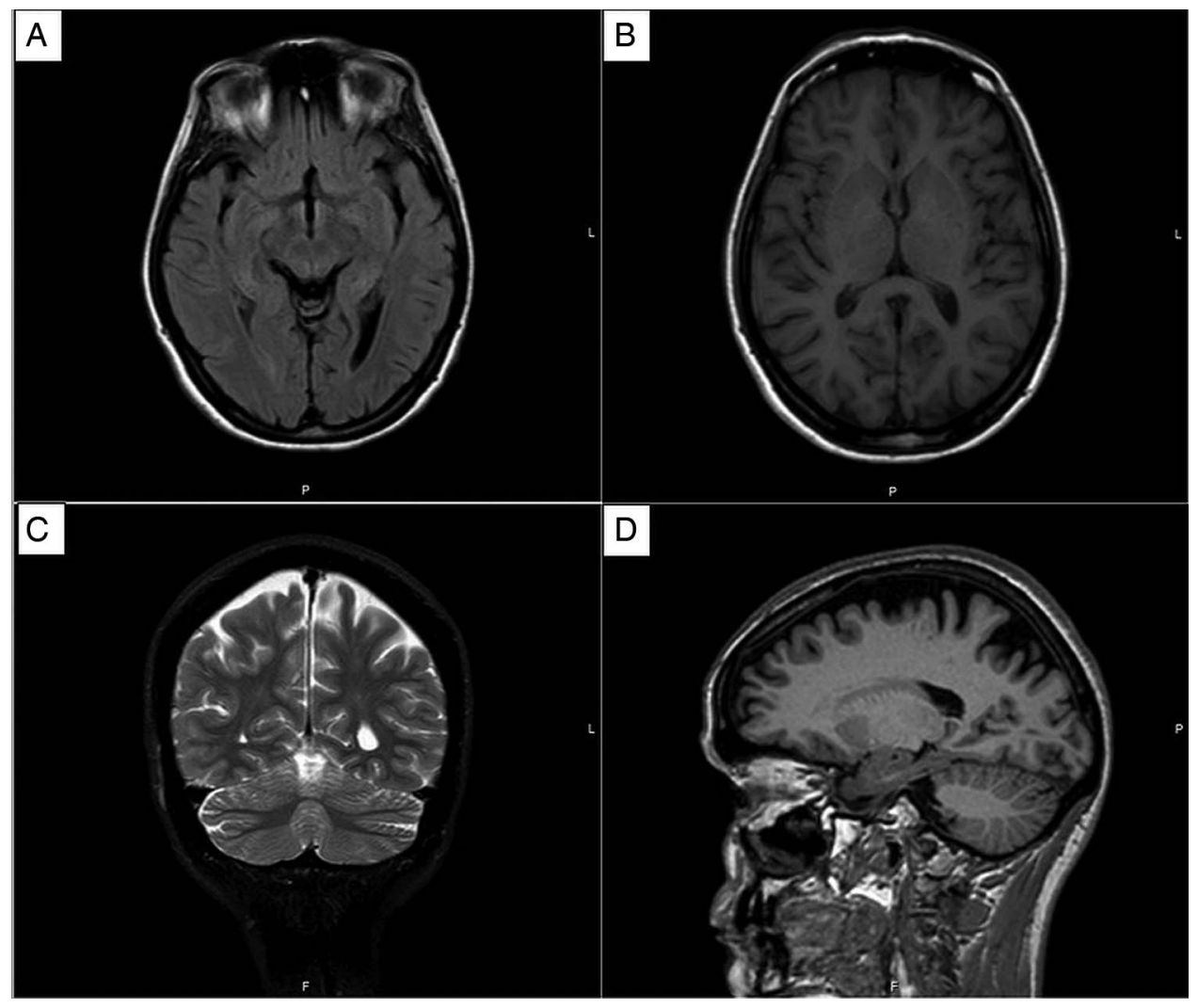

Figure $1 \mathrm{MRI}$ of the brain showing bilateral temporoparietal atrophy and lateral ventricular asymmetry. 


\section{Z Scored FFT Summary Information}
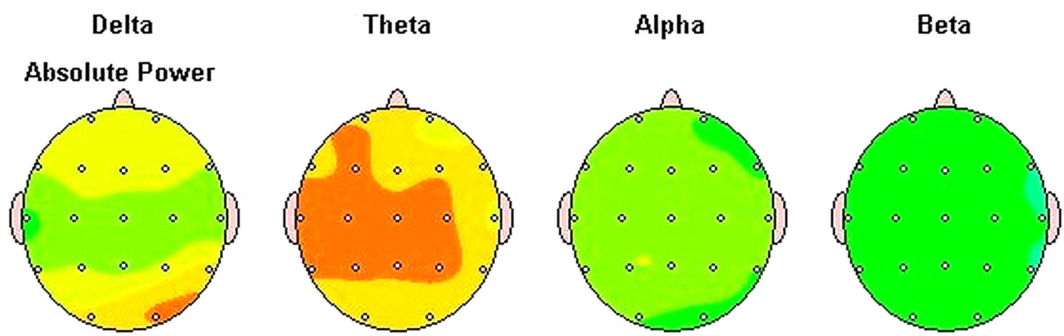

High Beta
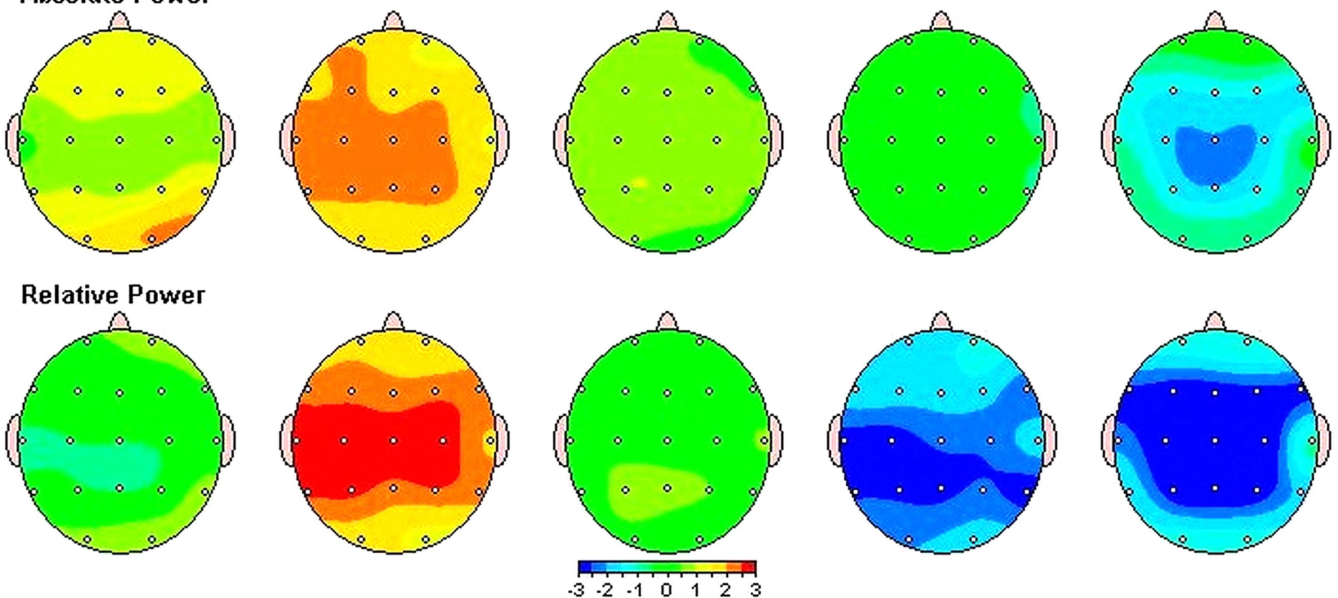

Figure 2 Quantitative electroencephalography of the brain showing increase $\theta$ and $\delta$ frequency.

\section{Z Scored FFT Summary Information}
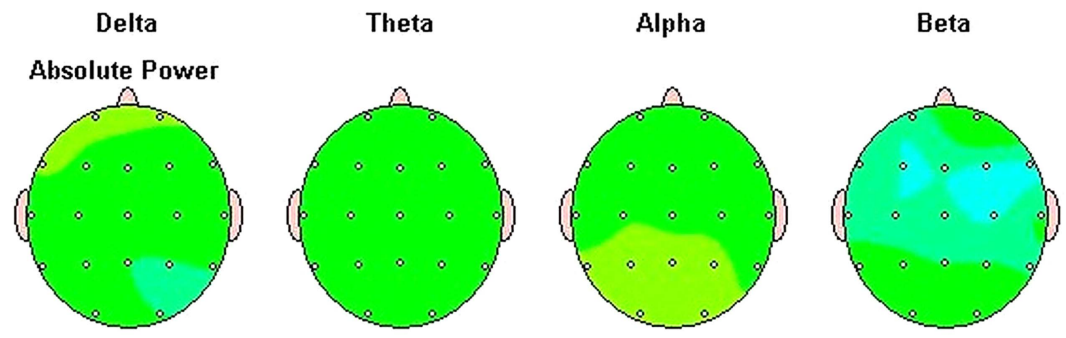

High Beta
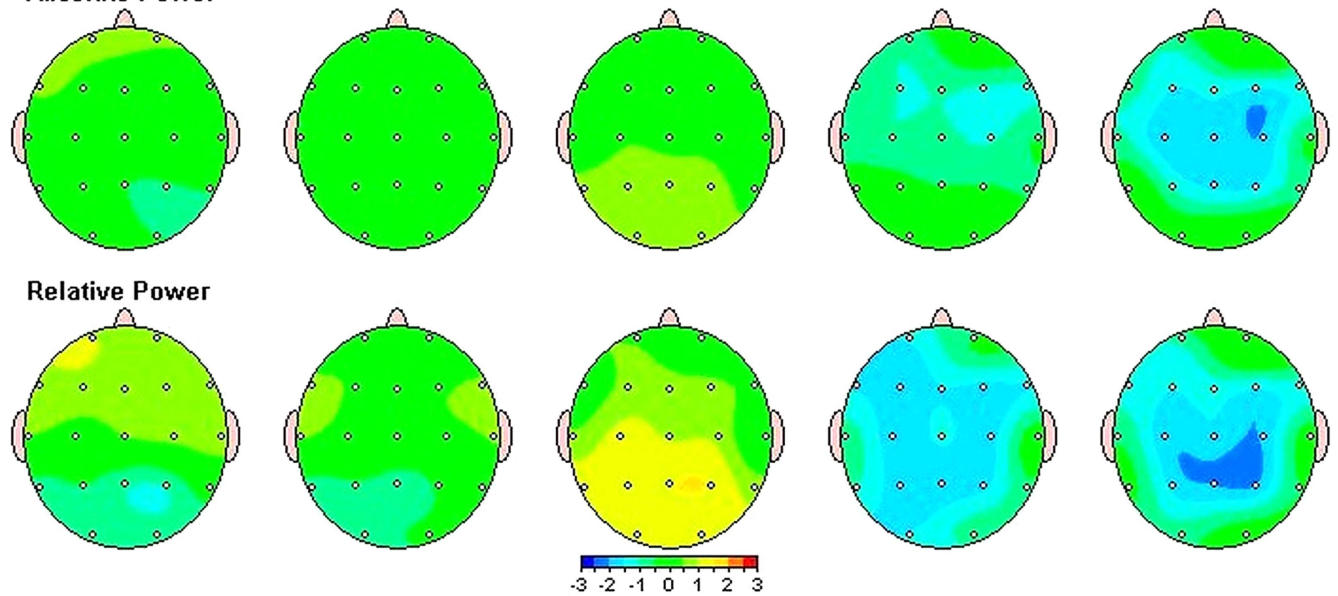

Figure $3 \theta$ and $\delta$ waves disappeared and q uantitative electroencephalography was normalised 6 weeks after lithium termination.

\section{Learning points}

- Long-term lithium use may cause cortical atrophy and cognitive dysfunctions.

- Patients who use lithium should be monitored with brain MRI.

Contributors AE wrote the case history and discussion. BÖÜ and MEC assisted with writing the case history. GC reviewed the manuscript.
Competing interests None.

Patient consent Obtained.

Provenance and peer review Not commissioned; externally peer reviewed.

\section{REFERENCES}

1 Hajek T, Kopecek M, Höschl C, et al. Smaller hippocampal volumes in patients with bipolar disorder are masked by exposure to lithium: a meta-analysis. J Psychiatry Neurosci 2012;37:333-43.

2 Wingo AP, Wingo TS, Harvey PD, et al. Effects of lithium on cognitive performance: a meta-analysis. J Clin Psychiatry 2009;70:1588-97.

3 Mora E, Portella MJ, Forcada I, et al. Persistence of cognitive impairment and its negative impact on psychosocial functioning in lithium-treated, euthymic bipolar patients: a 6-year follow-up study. Psychol Med 2013;43:1187-96. 
Copyright 2014 BMJ Publishing Group. All rights reserved. For permission to reuse any of this content visit http://group.bmj.com/group/rights-licensing/permissions.

BMJ Case Report Fellows may re-use this article for personal use and teaching without any further permission.

Become a Fellow of BMJ Case Reports today and you can:

- Submit as many cases as you like

- Enjoy fast sympathetic peer review and rapid publication of accepted articles

- Access all the published articles

- Re-use any of the published material for personal use and teaching without further permission

For information on Institutional Fellowships contact consortiasales@bmjgroup.com

Visit casereports.bmj.com for more articles like this and to become a Fellow 